\title{
Management of Group Work as a Classroom Activity
}

\author{
Eva Hammar Chiriac (Corresponding author) \\ Department of Behavioural Sciences and Learning, Linköping University \\ SE-581 83 Linköping, Sweden \\ Tel: 46-13-285-735 Fax: 46-13-282-145 E-mail: eva.hammar.chiriac@liu.se \\ Karin Forslund Frykedal \\ Department of Behavioural Sciences and Learning, Linköping University \\ SE-581 83 Linköping, Sweden \\ Tel: 46-13-285-618 Fax: 46-13-282-145 E-mail: karin.forslund.frykedal@liu.se
}

\author{
Received: June 5, $2011 \quad$ Accepted: July 12, $2011 \quad$ Published: October 1, 2011 \\ doi:10.5430/wje.v1n2p3 URL: http://dx.doi.org/10.5430/wje.v1n2p3
}

\begin{abstract}
Students appreciate group work as a means of learning and several studies also suggest that students who work together in groups have better learning outcomes. Nevertheless, teachers still seem reluctant to use group work as a pedagogical tool in the classroom.

The main focus of this qualitative study is to address group work as a classroom activity from the teachers' perspectives, and more specifically to ascertain why teachers are reluctant to use group work as a mode of working in education.

Data were collected by means of focus group interviews with teachers from three different schools, and the analysis was carried out using grounded theory.

The uniqueness of this study is that the results show that teachers' presumptions, together with their mode of procedure and their negligible reflections regarding subject knowledge as a learning outcome when using group work, have a decisive influence on their willingness to use group work.
\end{abstract}

Keywords: group work, classroom activity, teachers' experiences, leadership, teachership, presumptions

\section{Introduction}

There are mainly three ways to arrange classroom activity, namely whole-class lessons, group work or individual work (Granström, 1998, 2006). Each type of activity comprises its own pros and cons as well as specific preconditions for promoting or inhibiting learning and processes in the classroom. A teacher's choice of setting for students' learning may result in different challenges as well as enjoyment for both the teacher and the students. In this study we will focus on group work as we know that teachers and students do not always have the same preconceptions regarding group work. Students seem to appreciate group work as a classroom activity, while teachers appear more reluctant to use this mode of pedagogical practise (Hammar Chiriac, \& Granström, 2012; Gillies, \& Boyle, 2010). Another difficulty, which may cause problematic and unpredictable activities in the classroom, is that teachers and students, may interpret the assignment in various ways (Forslund Frykedal, 2008), and as a result both sides seem to proceed with different tasks during the same group work (Granström, 2006).

\subsection{Group work}

Group work is a way to organize classroom activity, where students are given a group assignment from the teacher and where the participants' equality and mutuality depends on how they engage in the group task, i.e., if they work cooperatively or collaboratively. Group work is customarily defined as 'pupils working together as a group or a team' (Blatchford, Kutnick, Baines, \& Galton, 2003, p. 155) or just 'students working together in small groups' (Lumpe, \& Haney, 1998, p 123), but it may be important to differentiate between working in a group and working as a group. Cooperative group work is often used carelessly as a description of group work in the classroom but may, according to Bennett and Dunne (1992) along with Galton and Williamson (1992), be a description of situations where students are sitting together in a group but are working individually on separate parts of a group assignment. At the end of the task 
the group members put the separate parts together into a joint product. Consequently, cooperative learning may occur in group work without any interaction between the students, i.e. working in a group. Members in cooperative groups could be working on divisible or unitary tasks (Hammar Chiriac, 2010, 2011; Steiner, 1972). This was confirmed in a study on the subject of classroom grouping practices in the UK (Baines, Blanchford, \& Kutnicks, 2003). The researchers found that the children were sitting together in groups but worked individually.

Collaborative group work, conversely, presupposes that all group members are involved in and working on a common task in order to produce a joint outcome (Bennett, \& Dunne, 1992; Galton, \& Williamson, 1992). Collaborative group work is characterized by a common effort and utilization of the group's competences, including problem solving and reflection, in other words working as a group or conjunctive group work (Steiner, 1972). The focus of this qualitative study is to address the teachers' perspective when using collaborative group work in the classroom.

Group work is highly appreciated by students as a means of learning and preparing for future work (Gillies, \& Boyle, 2010) and several studies also suggest that students who work together in groups tend to have better learning outcomes (Alandeom, \& Sadler, 2008; Bennett, Lubben, \& Campbell, 2004: Springer, Stanne, \& Donovan, 1999). Nevertheless, a number of teachers still seem reluctant to use group work as a pedagogical tool in the classroom (Gillies, \& Boyle, 2010). This tendency to use collaborative group work sparsely in the classroom seems to be valid across countries, as for instance in Sweden (Granström, 2006), the UK (Sanford, \& Evertson, 1983), the US (Schmuck, \& Schmuck, 1992) and Australia (Gillies, \& Boyle, 2010). One stated reason is that group work may give rise to classroom activities and processes among students, which might be difficult for the teacher to control (Gillies, \& Boyle, 2010; Granström, 2006). A second possible reason may be that teachers lack knowledge of how to manage group work and how to organize it in a profitable way (Gillies, \& Boyle, 2010; Lotan, 2006, 2008). Several authors stress the importance of ensuring that teachers have the opportunity for training in the management of group work as a classroom activity (Gillies, \& Boyle, 2010; Johnson, \& Johnson, 2003). Finally, previous negative experiences of using group work in the classroom may be the final conceivable explanation (Gillies, \& Boyle, 2010; Granström, 2006). To learn more about group processes and how to use them in a positive way as well as how to design group situations and tasks that acknowledge the group's potential for learning and development, may be two fruitful ways of reducing teachers' unwillingness to use group work as a means of learning. Following these feasible explanations for not using group work in classroom management, throughout this paper we intend to expose a complementary incentive for teachers' unwillingness to use group work teachers' preconceived ideas about group work as a classroom activity. Thus, a study concerning teachers' experiences and conceptions of group work as a classroom activity will be the next step in providing an increased understanding and may better explain the management of group work as a classroom activity.

In this study we directed our interest towards teachers, with the intention of acquiring more knowledge as to why they are unwilling to use group work as a mode of working in teaching even though research has established that students working together as groups tend to have better learning outcomes. Two theoretical concepts within the realm of classroom activity, leadership and teachership, have been beneficial, but not sufficient, for the understanding of teachers' management of group work as a classroom activity.

\section{Aims}

The main purpose of this investigation is to study group work as a classroom activity from the teachers' perspectives. A more specific aim is to explore and comprehend why teachers are reluctant to use group work as a mode of working in education.

\section{Previous Research on Group Work in the Classroom}

Two features of previous research are defined as central to this study, students' experiences and attitude towards group work and classroom management. The delimitation of previous research is foremost based on applicability since the analysis in this study is inspired by grounded theory.

\subsection{Students' experiences of and attitudes towards group work}

The most crucial aspect for learning in school according to students is the mode of working in the classroom (Granström, 2007). The mode of working has even more significance than, for instance, subject or class size. In spite of this, studies concerning group work from participants' perspectives still occur relatively seldom.

In recent years, a number of studies focusing on students' experiences and attitudes towards group work have emerged (Cantwell, \& Andrews, 2002;Forslund Frykedal, 2008; Hammar Chiriac, 2008, 2010; Hammar Chiriac, \& Einarsson, 2011; Hammar Chiriac, \& Granström, 2009, 2012; Hansen, 2006; Peterson, \& Miller, 2004; Underwood, 2003). Overall, the studies show a moderate enthusiasm for working in groups and the participants disclose both positive and negative experiences of this mode of working (Cantwell, \& Andrews, 2002; Peterson, \& Miller, 2004; Underwood, 2003). The 
students seem to prefer group work as a means of learning and well-being, but also emphasize that their learning profits from collaboration in groups (Gillies, \& Boyle, 2010; Hammar Chiriac, 2011; Hammar Chiriac, \& Einarsson, 2011; Hammar Chiriac, \& Granström, 2012). Hence, the students depict both positive and negative experiences from the mode of working. The joint conception is that there are some crucial aspects such as (a) group composition, (b) type of task, (c) work structure and (d) all group members should contribute to the group's common work (,Forslund Frykedal, 2008; Hammar Chiriac, 2011; Hammar Chiriac, \& Granström, 2012; Hansen, 2006; Underwood, 2003). Teachers' roles and attitudes during group work are also emphasized in several of the studies. A physically present and supportive teacher seems to be a crucial prerequisite for whether group work will be conceptualized as positive or negative.

\subsection{Classroom management}

Important incitements for good or bad group work, in students' opinions, are all closely connected to classroom management and need to be dealt with by the teacher. Hindrances to or prerequisites of group work are to some extent factors that teachers have to deal with when planning and realizing group work in their classrooms. Some studies indicate that teachers often choose a mode of working in the classroom based on their own preferences and work situation (Granström, 2006; Gillies, \& Boyle, 2010; Lumpe, \& Haney, 1998). Additionally, they are not always grounded in students' needs or evidence-based knowledge. One way for teachers to avoid difficult group processes, which may evolve in group work, is to choose whole-class lessons. On the other hand whole-class lessons might deprive the students of a powerful way of learning from each other and being prepared for future group work in real-life situations. Teachers argue that they have tried and abandoned group work as a mode of working in the classroom because of previous negative experiences, or because, in the teachers' words "it does not work". According to the teachers the students fail to take responsibility or do not learn enough (Granström, 2007; Gillies, \& Boyle, 2010).

Some teachers are unable or unwilling to delegate authority and let the students solve problems for themselves. They want to supervise the students and therefore prefer working with a small number of groups, preferably with an adult supervising each group (Cohen, 1994; Gillies, \& Boyle, 2010). Cohen (1994) has, nevertheless, shown that the greatest learning gains were obtained in classrooms where teachers successfully delegated authority. Since teachers control the students and refuse to assign any accountability to them, it is not essential for the students to take any responsibility for their own learning (Webb, Nemer, \& Ing, 2006). It is not until the teachers cease to control and thereby hand over responsibility to the students engaged in the task that the students will take charge of their own learning process. Hence, when teachers successfully delegate authority to the group the students start to collaborate and serve as resources for each other (Lotan, 2008).

\section{Leadership and Teachership}

The teachers' role in the classroom is significant and may be problematized in various ways in connection with classroom management and in implementing group work (Gillies, 2008; Gillies, Ashman, \& Terwel, 2008; Hammar Chiriac, \& Granström, 2009, 2012; Lotan, 2006; Webb, 2008). The teacher always has the utmost responsibility for all the actions and processes occurring in the classroom. Granström (2007) pinpoints that one task for teachers in the classroom is to be a supervisor over a group of students in their efforts to acquire knowledge. Thus, two important roles associated with classroom management are leadership and teachership. The concepts and requisites are defined as follows:

Leadership in the classroom:

- knowledge about classroom interaction and group processes

- ability to handle classroom interaction and group processes

Teachership in the classroom:

- knowledge of subjects

- ability to convey knowledge or proficiencies (Granström, 2007: p. 17)

The two roles complement each other and are both necessary, but not sufficient independently. A professional teacher practising his/her profession requires capabilities comprising both leadership and teachership. Leadership represents teachers' modes of procedure in classroom management and encompasses skills to plan, organize and accomplish classroom activities, for instance group work. In addition, the ideal leader has the ability to lead and activate the students irrespective of classroom practice. This teacher role is significant for all social courses of events in the classroom, but also for the relationship between all individuals involved. Teachership is the other side of the coin that represents teachers' modes of providing subject content and training in the classroom. An ideal teacher is highly skilled academically and has a great ability to convey knowledge to the students. Teachership comprises knowledge of subject 
content as well as knowledge of various modes or procedures to teach the subject matter. Teachership is essential for students' academic achievements as well as collaborative skills.

The definitions of leadership and teachership are not conclusive or comprehensive, but provide a picture of the features connected to the concepts and offer a possible way of investigating classroom management and teacher roles (Granström, 2007). There might be teachers who practise good or bad teachership as well as good or bad leadership in the classroom. To our knowledge, studies focusing on the teachers' perspectives on group work are still rare. Some exceptions are found, for instance Gillies, \& Boyle (2010), together with a few quantitative studies concerning teachers' beliefs and education in science through cooperative grouping (for instance Lumpe, \& Haney, 1998).

\subsection{Leadership and teachership as a symbolic interaction}

In addition to the two essential concepts of leadership and teachership in this study symbolic interactionism is employed as a complementary theoretical perspective. The use of symbolic interactionism enables an exposure of the processes in which the teacher is a part, but which also exerts an influence on their conceptions, communications and acts when using group work as a classroom activity. From a symbolic interactionistic point of view the surrounding world is perceived as social interpretations of meaning through a definition of the actual situation (Blumer, 1969; Charon, 2006; Goffman, 1959). People do not react immediately to the objective reality but instead to their interpretations of other people's actions (the act) and that which they, in interaction with their own thoughts, define in the situation, which is influenced by means of previous occurrences as well as thoughts about the future.

In social situations, as in group work, conceptions are shaped concerning constructed objects, which thereby become social objects with which individuals act in comparison (Blumer, 1969; Charon, 2006). The objects per se may be identical, but to separate individuals the social object becomes different since human beings define and create significance in different ways. Blumer (1969) denominates social objects, which several persons have in common, as joint objects. From these joint objects people create coordinated joint actions as a response to the way in which the definition has created significance towards the occurrence. In other words, it is possible to imply that when students and teachers assemble around group work, they apprehend and construct this act in a number of different ways depending on the separate individual's definition of the situation. Consequently, this is also a corollary to their actions, which entails that, in reality, the act evolves around different types of group work.

The review above reveals more systematic studies and documentation concerning teachers' reluctance to use group work as a mode of working in education, even though research has proved the opposite. Symbolic interactionism, leadership and teachership have been presented as scaffolding perspectives. The question is, are they relevant and sufficient in enhancing the knowledge of teachers' perspectives on group work in education and in particular in better explaining why teachers are reluctant to use group work as a mode of working in education.

\section{Method}

In order to capture teachers' experiences of using group work in classroom management a qualitative approach was chosen (Breakell, Hammond, Fife-Schaw, \& Smith, 2007; Bryman, 2001). Since the focus was on exploring a specific theme, focus groups were considered to be an effective and well-tried method for collecting data with reference to grasping meaning and content (Millward, 2007; Morgan, 1997). The research object may be described as a second order perspective, in other words, how the teachers experience and describe the phenomenon in question (Marton, 1988). A grounded theory inspired analysis was performed based on the transcriptions from the focus groups (Charmaz, 2006; Glaser, 1978; Glaser, \& Strauss, 1967; Strauss, \& Corbin, 1998).

\subsection{Focus group}

The use of focus groups as a research technique in this study was justified on the basis of including (a) a well-defined specific theme, (b) emphasis on interaction between participants, and (c) a joint construction of the meaning of the phenomenon studied (Bryman, 2001; Millward, 2007). The focus groups offer an opportunity to study how teachers in a group setting collectively discuss group work as a pedagogical tool. The purpose was to develop an understanding of how the teachers together construct a meaning of group work as a classroom activity and their own different behaviours when using group work in teaching.

\subsection{Participants}

The informants came from three schools in different counties in the south of Sweden (Table 1). Schools from different social and geographical areas were included and one focus group of teachers from each school participated in the study. Teachers, teaching students aged 11-16 years in compulsory education, are represented in the study. The teachers in a focus group could be from the same working team or just from the same school. The research group consisted of, in all, 
11 informants, 10 female and one male. Each focus group lasted a mean of 78 minutes, that is, a total data corpus of nearly four hours.

\section{$<$ Table 1 about here $>$}

Table 1 displays information about the focus groups. For reasons of confidentiality, information about the informants in each focus group will not be presented. The ages of the participants varied between young newly graduated teachers to older teachers with long experience in the teaching profession. The focus groups comprised teachers from several different subject fields, such as Swedish, mathematics, foreign languages, science, social studies, art, music and drama.

\subsection{Data collection}

The recruitment strategy used was intended to generate a positive interest, commitment and a high degree of cooperation from the schools (Millward, 2007). Initial contact with the head teachers at 12 schools provided a sparse result. Due to the difficulty in obtaining access to informants, a personal network of contacts at different schools was used to get in touch with interested teachers. Three focus group meetings were undertaken during a time frame of two months. The focus group sessions were conducted in the schools during the normal school day and the teachers used the time intended for planning or meetings to participate in the focus groups. Five questions were used to guide the interview in order to obtain the informants' own perspectives about group work as a classroom activity. The intention of the initial question was to encourage the participants to start talking and focus on the primary issue. The following questions were the actual research questions as the objective was to scrutinize group work from the teachers' perspectives. The questions concerned the teachers' use of group work as a classroom activity with particular emphasis on the following aspects: how, why, possibilities and hindrances.

The focus group meetings were carried out without any difficulties. Both researchers acted as moderators but in separate focus groups. Besides keeping the dialogue on track, the moderator also had to ensure that all questions were discussed. All teachers were actively involved in the discussion. Several informants also mentioned afterwards that they experienced an unexpected positive benefit from participating in the focus group.

\subsection{Analysis}

The discussions in the focus groups were audio taped and literally transcribed. The process of analysis began with several independent perusals of the data material while the researchers, at the same time, started to analyse the text by open coding (see for example, Charmaz, 2006; Glaser, 1978; Glaser, \& Strauss, 1967). During the first coding, several codes emerged, which in turn were elaborated and allocated into five categories: (a) compose groups; (b) keep the students busy; (c) keep the students as a group; (d) ability training; and (e) teaching group work. To refine the categories a theoretical sampling was completed and the dimensions within each category were defined. This was done by recoding the empirical data using the five categories. Based on the analyses and the coding process, memos surfaced. At this point of the analysis the two concepts, leadership and teachership, became sensitizing concepts for the continuing working process and became beneficial for the continuing analysis, since this elucidated the teachers' mode of proceeding when using group work in their teaching.

From this stage forward, the analyses divided the result into two distinctly different parts, the first pertaining to the two concepts. The other part emerged through constant comparative analysis and depicted a rather abstract concept concerning teachers' ideas about group work, presumptions. The ideas, as we later realized, had an extensive influence on the teachers' choice of classroom management. With the support of this third concept, presumption, it becomes possible to incorporate the teachers' ideas concerning the use of group work in the analysis. A conceptualized description of these three overriding concepts will follow in the results. The British Psychology Society's (BPS) four ethical principles based on (a) respect, (b) competence, (c) responsibility and (d) integrity have been practised throughout the study (BPS, 2006). In accordance with the ethical principals, concern for the participants' interests has been emphasized (APA (American Psychological Association), 2002; Barett, 2007; BPS, 2004). The quality in this qualitative research has been assured and measured based on validity and reliability (Bryman, 2001).

\section{Results}

In accordance with the overarching purpose, the results deal with group work as a classroom activity from the teachers' perspectives and especially deal with why teachers are reluctant to use group work as a mode of working in education.

Consequently, the results summarize teachers' apprehensions and behaviours when using collaborative group work in education. The presentation proceeds from the three concepts of leadership, teachership, and presumption, and is conceptualized by a set of sub-categories.

\subsection{Leadership}


Leadership represents teachers' modes of procedure when using group work in education. This concept is conceptualized by the three categories; compose groups, keep the students busy and keep the students as a group.

\subsubsection{Compose groups}

In all focus groups, the teachers show an awareness of and talk a lot about group composition. The informants express uncertainty relating to how to compose the ultimate groups. Usually the teachers compose the groups themselves, but occasionally they allow the students to compound the groups or simply leave it to sheer coincidence. On several occasions the teachers claimed to make conscious choices in order to create heterogeneous groups, taking into consideration ability, sex or even ambition. According to the informants, appropriate methods of composing groups often depend on the intention and objective of the group work.

I hardly ever let the students choose groups and such, because I decide whom they are supposed to work together with (focus group 2).

I can count, one, two three or ... something like that. Sometimes I let them [the students] decide, and sometimes not (1).

All informants allege that group composition is important to the students and is an aspect that may be criticized by the students, no matter which mode they utilize. However, the teachers seem to lack firm principles concerning group composition.

\subsubsection{Keep the students busy}

Teachers' classroom management when using group work might be compared to, as one teacher put it, an octopus. The teachers' ambitions are that the students shall be busy and engaged the whole time. Furthermore, the teachers are worried that the students do not work enough and therefore they feel obliged to be everywhere in order to supervise the students. It is important for the teachers that the students participate in group work; that is, they want the pupils to take an active part in the group work and not play truant, engage in other activities, play around or disturb other groups. Teachers seem to perceive group work as lacking in structure and therefore find it easier to work with other modes of classroom settings, for instance, whole-class lessons. Some of the teachers seem to crave shorter group work because "it's easier to manage". More extended group work entails more constant supervision of the students' work.

This free mode, or what you may call it, it's difficult for some of the students to get that kind of freedom. Just to be allowed to move around in the classroom. Group work often entails moving around from one place to another, for example, if you want to get some facts from the computer it's so easy to stay there for a while and just talk to a mate and so on. Several of the students are better off when they are just sitting in their workplace and listening to my instructions (3).

The teachers intend being present when the students' undertake group work and they consider it to be problematic to abandon them. The teachers do not dare to leave the pupils alone, especially not at the beginning of the group work, when they experience a need to help and support the group members to organize the group work and locate suitable material for the task.

\subsubsection{Keep the students as a group}

When discussing what the teachers assess with reference to group work they repeatedly emphasize the students'activity as a group through the assignments. In other words, participation, and the ability to (a) cooperate, (b) listen to each other and (c) communicate may be assessed regularly in conjunction with the final account. To "do one's bit / pull one's weight" seems to be an imperative rule. The teachers deem it hard work to keep the students as a group, partly because they aspire to be everywhere, to notice if anything happens and/or if they need to correct any misbehaviour.

You want to be everywhere and I think that's hard work. This entire muddle around group work makes it hard though. Sometimes, in the classroom where they work with group work you just stand and look around you wonder if anything is happening, if there is any work going on or if everybody is just messing around (3).

Sometimes the teachers need to calm down unpleasant displays and remind the students that they have a group task to attend to.

The conversations in the focus groups often converged towards group processes in the group work. The teachers implied that they sporadically focus on the production of the results but generally they walk around and listen in on the discussions, as well as observing how the group members work and behave and the degree of activity in the groups, that is, the students' activity as a group. During these rounds, the teachers implicitly assess the students' ability to listen to one another and how well they give and take instructions from each other. The teachers allege that they are assessing the working process and the students' 'way of working', as one teacher says.

In maths I assess their involvement and willingness instead of the results of the group work (3). 


\subsection{Teachership}

Teachership is the other side of the coin that represents the teachers' modes of presenting subject content and training when using group work as a classroom practice. This concept is conceptualized by two categories: group work as ability training and teaching group work.

\subsubsection{Ability training}

Teachers use group work for different purposes in their teaching, but they constantly underline the fact that collaboration is the keystone for all the time they spend together in the classroom. Additionally, they refer to the formal demands of the curriculum. The teachers want their students to develop personal skills and collaboration abilities during group work. Another purpose entails the students' learning to support each other and getting inspiration from the other group members when collaborating on a common task. The teachers believe that it is essential for the students to learn to communicate and talk about a subject continuously, as well as listening to the other members' contributions. As a result, the teachers prompt the students to be active both in the interaction between each other but also in the task at hand.

The teachers rarely talk about increasing subject knowledge in group work and in one of the schools they have decided not to use group work in language lessons in Form 9. They consider it more important for the students to acquire enough subject knowledge to reach the required curriculum levels instead of developing collaboration abilities. In general, the teachers seem reluctant to employ group work when it is imperative for the students to learn words, concepts and subject knowledge.

Thus, one way of working, well, you try to use several different ways but concerning language continuity it is very important. ... Hence, it might not be beneficial to use group work and such. It's imperative to know very many words and you need a high proficiency. Thus, sometimes you can use group work, about countries or music, you know. But concerning languages and similar... In my opinion, it's mostly Swedish that promotes group work and such (1).

Thus, the teachers are not convinced of the advantages of group work for academic learning and subject knowledge.

\subsubsection{Teaching group work}

The teachers do not educate the students in group work abilities, in other words, how to (a) structure group work, (b) take different roles or (c) handle group processes. In contradiction to the teachers' premeditated concern about how to compose groups, they admit that they seldom teach how to conduct group work. The teachers acknowledge the assignment to be important and purport that they give instruction about the task and how to organize it, as well as instructions about textbooks and homepages on the Internet. Inspiring the students is distinguished as an ancillary important responsibility for the informants and this encouragement is often accomplished in connection with the introduction of the subject. In summary, one possible interpretation is that teachers teach the subject but do not teach the mode of working when using group work as classroom management.

To sum up, the use of the concepts of leadership and teachership elucidate the teachers' ambitions when using group work in the classroom, but explain nothing about the causes that linger behind their behaviours, such as why they are reluctant to use group work as a classroom activity. To interpret and understand the teachers' actions a complementary concept is necessary. One option is to use the teachers' ideas with regard to group work presumption, and thereby gain a more complete reflection of the teachers' experiences in group work and their willingness to use this mode of pedagogical activity.

\subsection{Presumptions pertaining to group work}

From the detailed material it became evident that the teachers' ideas with regard to group work play an important role. The teachers' presumptions about (a) collaboration as a classroom setting, (b) students' attitudes towards group work, (c) students' ways of learning and (d) context, time and space, are important incitements for the teachers' willingness to use group work. The last part of the results comprises a conceptualized description of the requisite third concept, presumption.

\subsubsection{Presumptions about collaboration as a classroom setting}

The results reveal that the teachers included in this study have hardly any common conceptions or language when discussing collaboration in the classroom. The teachers give students' collaboration various different names, such as: theme, group work, teamwork, mini-group work, group discussions, work together, work in groups, collaboration, cooperation etc. In addition, there are several different opinions related to how frequently collaboration in the classroom occurs, with a range from every day to once a week, depending on the teachers' conception of collaboration. For instance, the students may help each other or work together during shorter periods, from 10 minutes upwards. 
It may be very short periods ... (2).

I was going to say every day, but perhaps not just that often (2).

Further, the teachers argue that it is more common to organize shorter and clearly defined group work, so called 'mini-groups' than extensive longer ones. Hence, 'mini-groups' are used by many of the teachers once or twice a week and consist of discussions, problem solving, laboratory experiments etc. Extended group work, such as teamwork and projects, are uncommon and more difficult to carry through.

Group work seems to be usable as a classroom setting and is in fact employed in all subject fields represented in this study, although to a varied extent. When the teachers describe more organized group work as classroom management the same tendency becomes evident; there are very few, if any, common features connecting the different teachers' descriptions of group work in the classroom. The impression is that group work is considered as interplay rather than a pedagogical approach.

6.3.2 Presumptions about students' attitudes towards group work

Regarding the teachers' conceptions of students'attitudes towards working in groups three main ideas are distinguished. The first idea is that the teachers volunteer the information that the students are positive towards concise, uncomplicated group work in smaller groups. The reasons proposed by the informants are that the pupils feel more secure and comfortable when working in minor groups, which in turn enhances the possibility of uncomplicated collaboration. Shorter group work is easier for the students to grasp and is not so challenging. If the group work is concise, easy to grasp and carried out in small groups the pupils' resistance decreases.

The second idea, relating to teachers' opinions about the students' attitudes, states that the attitudes evolved from different ambitions, knowledge, ability, social relations, age and/or responsibility create resistance towards group work by the students. Above all, students with high ambition, high knowledge and academic ability aspire to work in the company of their equals. If the pupils have to work with classmates with lower ambitions they are worried about having to help the others to a great extent and thus resist group work in preference to individual work.

There are students who think that group work is the most awful mode of working, because they have a rough time since the others just catch a free ride (3).

As mentioned before, the teachers often receive complaints from the students vis-à-vis group composition, and they insist on working with friends or classmates with the same ambitions, especially if they want to compose their own groups. The third idea, relevant to pupils' attitudes, alleges that the students are individualists and quite often competitors, which implies that they may have difficulty in being 'one of the crowd'; on the contrary they like to stand out in the group. The teachers propose that the collective does not entrust the individual and therefore the students are opposed to group work and favour individual work.

The collective is no longer what it used to be and even in a collective situation you maintain your right and your entitlement to do as you like (3).

The teachers also imply that the students have preconceived opinions about each other, which hamper them in gaining knowledge of each other's capabilities. Students also like to know why they have to follow the teacher's suggestions on how to perform the work. The teachers interpret these actions as resistance towards group work and that individualism is prevailing over group work. However, the teachers' idea is that if group work is compulsory then the assignment should be concise, uncomplicated and carried out in small groups composed of homogenous group members with respect to ability.

6.3.3 Presumptions about students' ways of learning

The teachers put forward the argument that the students learn more effectively when working individually, and not through collaboration with other students. One of the teachers expresses herself with the following words:

The serious danger jeopardy with group work, it's easy "to atomize", as you mention, you only learn the part you worked not your mates' parts (3).

A common idea among the informants is that knowledge of the subject is learned through individual work and the teachers find it difficult to convey their knowledge on a subject to students working in groups. Accordingly, the participants in the focus groups seldom discussed subject knowledge in connection with group work. Two statements illustrate this joint view.

If you are going to manage the curriculum you can't use group work (1).

If you like to achieve lifetime learning it's impossible to use small-group work (3). 
A group of teachers discussed the importance of learning concepts hampering the use of group work. The students have to gain knowledge of the concepts initially during individual work and only subsequently when the concepts are known is it possible for the student to use them in connection with group work.

In my view there's a hindrance for group work in science when knowledge becomes separate islands difficult to tie together There're so many concepts you have to learn, often a chain of actions. And you can't just know a little about the principle of lever actions to grasp the law of gravity or the concept of mass. You really have to understand what the concepts, both mass and volume, stand for, so then it's impossible to use group work as you actually have to work with all the concepts and then solve the assignment by using the concepts (3).

On the other hand, if the students are supposed to work with problem solving, such as solving mathematical problems, group work excels over individual work. The same is valid for the development of communication and languages, which, according to the informants, is best achieved in meeting with others. Furthermore, the teachers claim that it is in the group that the students develop as individuals and learn to talk and listen to each other as well as to converse with a variety of people.

Group work deals a lot with pupils getting a joint communicative picture together and letting them grow as individuals (3).

The work or the product in group work creates surplus value, more than the individual could have achieved on their own (3).

It is evident that teachers consider groups as a form for social rather than academic training.

\subsubsection{Presumptions about context, time and space}

The results indicate that teachers have ideas on how the context may facilitate or hamper the use of group work as a classroom setting. This seems to be a more dominant issue in some schools than in others, and there it is mostly time and space that are emphasized.

The time aspect seems to be a common denominator, irrespective of place or form, mainly because of the timetable that divides the school day into short periods, often too short for group work. The timetable at the senior level (students aged 14-16) in compulsory education also subdivides the time into brief spheres of activity concerning various subjects, each subject with its own specialized teacher.

It's exactly as she says, a very traditional [timetable], she has only 40 minutes. What can she achieve in 40 minutes if she wants to arrange some larger group work, or actually go to the computer classroom? And what can I teach in my 50 minutes, which I have in social studies ... If I want to go out on an educational visit or do something extensive, I've to ask, as when we went on a field trip to the police, then I'd to ask everybody and alter everything. It's a very big thing because I've to intrude on someone else's lesson and other students don't get a teacher for their lesson. Accordingly, it's to do with a lot of such things, a lot of such boring [things] (1).

In the lower level (forms 11-13) of the school system one teacher is responsible for the class during most of the day. The problem emphasized by the informants is that 'the time is too short', group work is time-consuming and requires more time than just the period of time allotted in the school schedule.

The other aspect relates to space and location and appears to be connected to the school in which the informants are working. A school cramped for space is more vulnerable when it comes to finding locations for pupils to conduct group work. Instead, all groups must work in the same classroom.

It's very true, what X [one of the informants] says, because we are very cramped for space here. We don't have any group rooms, where the pupils may sit in private and work on their tasks (1).

According to teachers' presumptions they are responsible for the students during school hours and are reluctant to let the students out of their sight. To let the groups disappear to unsupervised parts of the school is therefore out of the question.

That's a fact! You can't leave them, because we are responsible for the pupils in the classroom. (...) So we only have our classroom and we are situated in another building. So if we want to cooperate and spread out a little or stay in peace and quiet we must go up there (1).

The question of furnishings is also mentioned. A classroom may be furnished in accordance with facilitating group work or vice versa. In some schools there might even be tension between colleagues or even with the cleaners concerning how to furnish the classroom.

\section{Conclusion}

The teachers have, in their version, presented their experiences of managing group work as a classroom activity and their 
approach towards group work when using it as a classroom activity. In addition to their reluctance to use group work as pedagogical tool, the theoretical concepts leadership and teachership have been beneficial, but not sufficient, in understanding the teachers' mode of proceeding when using group work (Granström, 2006; Gillies, \& Boyle, 2010; Lumpe, \& Haney, 1998). With the use of symbolic interactionism as a point of departure, a complementary concept, presumption, was included to enhance knowledge and understanding about the causes lingering behind teachers' statements about group work and why they are unwilling to use group work as a mode of working.

The result reveals a connection between the teachers' use of, and their presumptions concerning, group work, influencing how they approach group work as a mode of teaching. The informants' statements clearly demonstrate that they primarily expect the students to develop the ability to collaborate, and not principally to acquire subject knowledge, during group work. In addition the teachers express a concern that the students will have difficulties in 'managing the curriculum' and 'achieving lifelong learning' if group work is used as a pedagogical tool. Teachers also seem very anxious about keeping the students as a group by means of the assignment, which might depend on their ambition to develop the students' abilities to collaborate. The teachers have difficulty in being everywhere and ensuring that the students are working actively. However, according to Lotan (2008) and Cohen (1994) it is not until the teachers successfully delegate authority to the group that the students start to collaborate and act as resources for each other. Furthermore, the teachers express apprehension about students encompassing a negative attitude towards group work and the advantages of individual work. Conversely, previous studies regarding student's attitude towards group work, display both positive and negative considerations (Cantwell, \& Andrews, 2002; Forslund Frykedal, 2008; Hammar Chiriac, 2011;Hammar Chiriac, \& Einarsson, 2011; Hammar Chiriac, \& Granström, 2012; Hansen, 2006; Peterson, \& Miller, 2004; Underwood, 2003). In accordance with the teachers' presumptions, the contextual difficulties, including time and space, might hamper the teachers' employment of group work in classroom management. The result is confirmed by previous research concerning teachers' beliefs and cooperative grouping in science education (Lumpe, \& Haney, 1998).

How is it that the teachers in this study do not believe that group work promotes subject knowledge, even though several studies have proved that students working together in groups tend to have better learning outcomes compared to other forms of working (Alandeom, \& Sadler, 2008; Bennett et al., 2004; Springer et al., 1999)? Our supposition is that teachers do not believe that their students are able to acquire subject knowledge when using group work, as they think that they have caught such signals from the students. Consequently, in line with symbolic interactionism, the teachers' choice of content during group work does not encourage the students to develop academic knowledge or skills. As a result of this interactional dynamic the teachers lack experience of group work as an ingenious form of acquiring subject knowledge.

\section{Discussion}

\subsection{Management of group work as a classroom activity}

In this study the informants' statements clearly demonstrate that they primarily expect the students to develop the ability to collaborate, and not to acquire subject knowledge, during group work. Teachers also seem very anxious about keeping the students as a group within the assignment, which might be connected with the presumption that the activity aims to train and develop the students' abilities to collaborate. The teachers express difficulties in being everywhere and ensuring that the students are busy. According to Cohen (1994) as well as Gillies and Boyle (2010) some teachers are unable or unwilling to delegate authority and let the students solve problems for themselves. They want to supervise the students, preferably with an adult supervisor in each group. But nevertheless, the greatest learning gains were obtained in classrooms where teachers successfully delegated authority, and it is not until the teachers cease to control, and thereby hand over the responsibility to the students engaged in the task, that the students will take charge of their own learning processes (Cohen, 1994; Gillies, \& Boyle, 2010; Webb et al., 2006). When teachers successfully delegated authority to the group the students started to collaborate and served as resources for each other (Lotan, 2008).

\subsection{Leadership, teachership and presumption}

The two concepts of leadership and teachership, introduced by Granström (2007), have been beneficial for a more profound understanding of the teachers' accounts. Leadership comprises knowledge about interaction and group processes and an ability to lead, organize and cope with these activities, while teachership encompasses both subject knowledge and the ability to convey knowledge of proficiencies. As shown in Table 2, which summarizes the results, it seems as if teachers above all employ leadership when using group work as a classroom activity. This approach could be explained by the fact that they primarily expect the students to develop the ability to collaborate, and not to acquire subject knowledge. Even when the teachers utilize teachership the aim seems to be to develop abilities that might be useful in classroom interactions as well as in collaboration between students. Discussions about the students' acquisition 
of subject knowledge rarely occur, which implies that the teachers hardly ever use the approach of teachership. Based on symbolic interactionism, the concept of presumption was constructed and defined as follows: presumptions include (a) ideas about the teacher's own subject knowledge and his/her ability to convey this knowledge through group work and (b) ideas about the teacher's own knowledge about classroom interaction and group processes and his/her ability to organize and handle the interaction and the group processes.

The results pertaining to teachers' presumption resemble previous findings from studies comprising teachers' beliefs and cooperative grouping in science education (Lumpe, \& Haney, 1998). In this trajectory, researchers have used the Theory of Planned Behaviour to assess the influence of teachers' salient beliefs to employ cooperative learning in the classroom. Even though there are some differences between the concept of salient beliefs (Lumpe, \& Haney, 1998) and our use of presumptions the results point in the same direction; that is teachers' presumptions or beliefs are an important factor concerning the teachers' willingness to employ group work as a classroom activity.

The concept of presumption has increased the knowledge and understanding of the teachers' modes of proceeding as well as their reluctance to use group work, since it encompasses the teachers' presumptions about: (a) what constitutes group work, as well as (b) students' attitudes, (c) possible learning outcomes and (d) hindrances when using group work as a classroom activity. From a symbolic interactionism point of view, the surrounding world is perceived as social interpretations of meaning through a definition of the existing situation (Blumer, 1969; Charon, 2006; Goffman, 1959). Blumer (1969) alludes to the presence of both a subjective experience, generated within each individual, and an objective created setting of significance, which together influence the individual's definition of the situation. These two assumptions are influenced by means of previous occurrences, as well as thoughts about the future. If the teachers' definitions of the situation, thoughts about the past and the future, do not include anything about subject knowledge as a learning outcome then it is obvious that it is not demonstrated in their method of proceeding and they become unwilling to use group work as pedagogical tool.

A summarized picture of the results and the discussions above is shown in Table 2.

$<$ Table 2 about here $>$

From a symbolic interactionistic perspective the teachers' presumptions exert an influence on their willingness to use group work. The table elucidates how teachers' presumptions exert an influence on both leadership and teachership. These interactions, with their own thoughts defined in the situation, are influenced by previous experiences as well as thoughts about the future, thus the teachers' approaches and willingness to use group work are forcefully influenced by their conceptions.

The uniqueness of the results in this study is two-fold: first it discloses that teachers' presumptions, with regard to group work in general and the willingness to use group work specifically, play a decisive role in whether or not group work will be chosen as a classroom activity. The second unanticipated result concerns the teachers' negligible reflections as regards subject knowledge as a learning outcome when using group work as a classroom activity. The teachers do not expect students to learn subject knowledge from group work, but to learn collaborative abilities.

\section{References}

Alandeom, O., \& Sadler, T. (2008). Interactive patterns and conceptual convergence during student collaborations in science. Journal of Research in Science Teaching, 26, 634-658, http://dx.doi.org/10.1002/tea.20211

American Psychological Association (APA). (2002). The ethical principles of psychologists and code of conduct. Retrieved August 2, 2008 from http://www.apa.org/ethics/code2002.html

Baines, E., Blatchford, P. and Kutnick, P. (2003) Changes in grouping practices in primary and secondary school. International Journal of Educational Research, 39, 9-34. http://dx.doi.org/10.1016/S0883-0355(03)00071-5

Barett, M. (2007). Practical and ethical issues in planning research. In G. Breakell, S. Hammond, C. Fife-Schaw, \& J.A Smith (Eds.), Research methods in psychology (pp. 24-48). London: SAGE Publications.

Bennett, N., \& Dunne, E. (1992). Managing classroom groups. Hemel Hempstead: Simon \& Schuster Education.

Bennett, J., Lubben, F., \& Campbell, B. (2004). A systematic review of the use of small-group discussions in science teaching with students aged 11-18, and their effects on students' understanding in science or attitude to science: Review summary. York: University of York.

Blatchford, P., Kutnick, P., Baines, E., \& Galton, M. (2003) Toward a social pedagogy of classroom group work. 
International Journal of Educational Research, 39, 153-172, http://dx.doi.org/10.1016/S0883-0355(03)00078-8

Blumer, H. (1969). Symbolic interactionism: Perspective and method. Berkeley, CA: University of California Press.

Breakell, G., Hammond, S., Fife-Schaw, C., \& Smith, J. A. (Eds.) (2007). Research methods in psychology. London: SAGE Publications.

British Psychology Society (BPS). (2004). Code of conduct, ethical principles \& guidelines. Retrieved August 2, 2008 from http://www.bps.org.uk/document-download-area/document-download\$.cfm?file_uuid=6D0645CC-7E96-C67F-D7 5E2648E5580115\&ext=pdf

British Psychology Society (BPS). (2006) Code of ethics and conduct. Retrieved August 2, 2008 from http://www.bps.org.uk/the-society/code-of-conduct/code-of-conduct_home.cfm

Bryman, A. (2001). Social research methods. Oxford: Oxford University Press.

Cantwell, R. H., \& Andrews, B. (2002). Cognitive and psychological factors underlying secondary school students' feelings towards group work. Educational Psychology, 22, 75-91, http://dx.doi.org/10.1080/01443410120101260

Charmaz, K. (2006). Constructing grounded theory. London: SAGE Publications.

Charon, J. M. (2006). Symbolic interactionism: An introduction, an interpretation, an integration (9th ed.). London: Prentice Hall.

Cohen, E. G. (1994). Restructuring the classroom: Conditions for productive small groups. Review of Educational Research, 64, 1-35, http://dx.doi.org/10.3102/00346543064001001

Forslund Frykedal, K. (2008). Elevers tillvägagångssätt vid grupparbete. Om ambitionsnivå och interaktionsmönster i samarbetssituationer. [Students' course of action in groupwork: On levels of ambition and patterns of behaviour in collaborative situations.] (Linköpings Studies in Behavioural Science no 128). Linköping: Linköping University.

Galton, M., \& Williamson, J. (1992). Group work in the primary classroom. London: Routledge.

Gillies, R. M. (2008). Teachers' and students' verbal behaviours during cooperative learning. In R. M. Gillies, A. Ashman, \& J. Terwel (Eds.), The teacher's role in implementing cooperative learning in the classroom (pp. 243-262). Brisbane: Springer. http://dx.doi.org/10.1007/978-0-387-70892-8_12

Gillies, R. M, Ashman, A., \& Terwel, J. (2008). Concluding remarks. In R. M. Gillies, A. Ashman, \& J. Terwel (Eds.), The teacher's role in implementing cooperative learning in the classroom (pp. 263-266). Brisbane: Springer. http://dx.doi.org/10.1007/978-0-387-70892-8

Gillies, R. M., \& Boyle, M. (2010). Thachers' reflection on cooperative learning: Issues of implementing. Teaching and Teacher Education, 26, 933-940, http://dx.doi.org/10.1016/j.tate.2009.10.034

Glaser, B. G. (1978). Theoretical sensitivity. Mill Valley, CA: Sociology Press.

Glaser, B. G., \& Strauss, A. (1967). The discovery of grounded theory. Strategies for qualitative research. Hawthorne, New York: Aldine de Gruyter.

Goffman, E. (1959). The presentation of self in everyday life. New York: Anchor Books.

Granström, K. (1998). Classroom management in Sweden. In N. Shimahara (Ed.), Politics of classroom life. Classroom management in international perspective (pp. 136-162). New York: Garland Publisher.

Granström, K. (2006). Group phenomena and classroom management in Sweden. In C. M. Evertson, \& C. S. Weinstein (Eds.), Handbook of classroom management: Research, practice, and contemporary issues. (pp. 1141-1160) Mahwah: Lawrence Erlbaum Associates, Publisher.

Granström, K. (2007). Ledarskap i klassrummet [Leadership in the classroom]. In K. Granström, (Ed.), Forskning om lärares arbete $i$ klassrummet [Research into teachers work in the classroom] (pp.13-32). Stockholm: Myndigheten för skolutveckling. [The authority for school development].

Hammar Chiriac, E. (2008). A scheme for understanding group processes in problem-based learning. Higher Education, 55, 505-518. http://dx.doi.org/10.1007/s10734-007-9071-7

Hammar Chiriac , E. (2010). Group work is not one, but a great many processes - Understanding group work dynamics. In C. W. Danellis (Ed.), Group theory: Classes, representation and connections, and applications (in press). NY: Nova Science Publishers, Inc. 
Hammar Chiriac , E. (2011). Research on group work in education. In F. Columbus (Ed.) Emerging issues in compulsory education (pp. 25-44). New York: Nova Science Publishers, Inc.

Hammar Chiriac E., \& Einarsson, C. (2011). Group work as success or failure - students' experiences of group work (in prep).

Hammar Chiriac , E., \& Granström, K. (2009). Prerequisites for meaningful group work - Students' experiences of co-operation. In S. Jern, \& J. Näslund (Eds.), Dynamics within and outside the lab: Proceedings from the 6th Nordic Conference on Group and Social Psychology, Lund University, May, 2008. Linköping: Linköping University.

Hammar Chiriac, E. \& Granström, K. (2012). Teachers' leadership and students' experience of group work. Teachers and Teaching: Theory and Practice, volym $18 \mathrm{nr} 3$.

Hansen, R. S. (2006). Benefits and problems with student teams: Suggestions for improving team projects. Journal of Education for Business, 1, 11-19. http://dx.doi.org/10.3200/JOEB.82.1.11-19

Johnson, D., \& Johnson, F. (2003). Joining together: Group theory and group skills. Boston: Allyn and Bacon.

Lotan, R.A. (2006). Managing groupwork in the heterogeneous classroom. In C. M. Evertson, \& C. S. Weinstein (Eds.), Handbook of classroom management: Research, practice, and contemporary issues (pp. 525-540). Mahwah: Lawrence Erlbaum Associates, Publisher.

Lotan, R.A. (2008). Developing language and mastering content in heterogeneous classrooms. In R. M. Gillies, A. Ashman, \& J. Terwel (Eds.), The teacher's role in implementing cooperative learning in the classroom ( $\mathrm{pp}$. 187-203). Brisbane: Springer. http://dx.doi.org/10.1007/978-0-387-70892-8_9

Lumpe, A.T., \& Haney, J.J. (1998). Science teachers' beliefs and intentions regarding the use of cooperative learning. School Science and Mathematics, 3, 123-135, http://dx.doi.org/10.1111/j.1949-8594.1998.tb17405.x

Marton, F. (1988). Phenomenography: A research approach to investigating different understandings of reality. In R.R. Sherman, \& R.B. Webb (Eds.), Qualitative research in education: focus and methods (pp. 141-161). London. The Falmer Press.

Millward, L. J. (2007). Focus groups. In G. Breakell, S. Hammond, C. Fife-Schaw, \& J. A Smith (Eds.), Research methods in psychology (pp. 274-292). London: SAGE Publications.

Morgan, D. L. (1997). Focus groups as qualitative research. London: SAGE Publications.

Peterson, S. E., \& Miller, J. A. (2004). Quality of college students' experiences during cooperative learning. Social Psychology of Education, 7, 161-183, http://dx.doi.org/10.1023/B:SPOE.0000018522.39515.19

Sanford, J. P., \& Evertson, C. M. (1983). Time use and activities in junior high classes. Journal of Educational Research, $63,143-147$.

Schmuck, R. A., \& Schmuck, P. A. (1992). Group processes in the classroom. Dubuque: William C. Brown.

Springer, L., Stanne, M. E., \& Donovan, S. S. (1999). Effects of small-group learning on undergraduates in science, mathematics, engineering and technology: A meta-analysis. Review of Educational Research, 69, 21-51, http://dx.doi.org/10.3102/00346543069001021

Steiner, I.D. (1972). Group process and productivity. New York: Academic Press.

Strauss, A., \& Corbin, J. (1998). Basics of qualitative research. London: SAGE Publications.

Underwood, J. D. M. (2003). Student attitudes towards socially acceptable and unacceptable group working practices. British Journal of Psychology, 94, 319-337, http://dx.doi.org/10.1348/000712603767876253

Webb, N. M. (2008). Teacher practices and small-group dynamics in cooperative learning classrooms. . In R. M. Gillies, A. Ashman, \& J. Terwel (Eds.), The teacher's role in implementing cooperative learning in the classroom (pp. 205-226). Brisbane: Springer. http://dx.doi.org/10.1007/978-0-387-70892-8_10

Webb, N. M., Nemer, K. M., \& Ing, M. (2006). Small-group reflections: Parallels between teacher discourse and student behavior in peer-directed groups. The Journal of the Learning Sciences, 15, 63-119, http://dx.doi.org/10.1207/s15327809j1s1501_8 
Table 1. Details of the focus groups

\begin{tabular}{|c|c|c|c|}
\hline Focus group & School & Participants & Time (min) \\
\hline 1 & A-School & 3 & 97 \\
\hline 2 & B- School & 4 & 76 \\
\hline 3 & C- School & 4 & 60 \\
\hline
\end{tabular}

Table 2. How teachers' considerations affect leadership and teachership when using group work

\begin{tabular}{|c|c|c|c|}
\hline Approach & Presumptions & Leadership & Teachership \\
\hline Compose groups & $\begin{array}{l}\text { The students choose } \\
\text { individual work in } \\
\text { preference to group work }\end{array}$ & $\begin{array}{l}\text { Conscious choices in } \\
\text { order to compose groups }\end{array}$ & \\
\hline Keep the students busy & $\begin{array}{l}\text { Presumptions about time } \\
\text { and space hamper the } \\
\text { organization of group } \\
\text { work }\end{array}$ & $\begin{array}{l}\text { Control the students' } \\
\text { activity by assignment } \\
\text { and supervision }\end{array}$ & \\
\hline Keep the students as a group & $\begin{array}{l}\text { Presumptions about time } \\
\text { and space hamper the } \\
\text { organization of group } \\
\text { work }\end{array}$ & $\begin{array}{l}\text { Create assignments which } \\
\text { keep the students as a } \\
\text { group }\end{array}$ & \\
\hline Ability training & $\begin{array}{l}\text { No joint description of } \\
\text { what constitutes group } \\
\text { work }\end{array}$ & & $\begin{array}{l}\text { Create learning } \\
\text { environments which } \\
\text { facilitate the students' } \\
\text { learning of collaboration } \\
\text { abilities }\end{array}$ \\
\hline Teaching group work & $\begin{array}{l}\text { The students learn subject } \\
\text { knowledge through } \\
\text { individual work and } \\
\text { collaboration abilities } \\
\text { through group work }\end{array}$ & & $\begin{array}{l}\text { Give instruction about the } \\
\text { task and how to organize } \\
\text { it. Inspire/ encourage the } \\
\text { students during the } \\
\text { introduction of the subject }\end{array}$ \\
\hline
\end{tabular}

